\title{
Information Literacy and Doctoral Students in France and Poland. A Comparative Study
}

\author{
Zuzanna Wiorogórska \\ The University of Warsaw Library \\ Laboratoire GERiiCO, Université Lille Nord de France
}

\begin{abstract}
Purpose/thesis: The purpose of this paper is to discuss the issue of information literacy (IL) in view of French-Polish comparative research on information users. In the first part of the paper the similarities and differences in Polish and French approaches to information literacy are analyzed from the perspective of higher education. Next, the results of research conducted among doctoral students at the University of Warsaw and the University of Lille are presented.

Approach/methods: Three methods were used: survey, nonparticipant observation and elements of grounded theory. The research tended on the one hand to verify the hypothesis on a low use of scientific journals by doctoral students, and on the other hand to answer the question what librarians and faculty should do to increase this use.

Results and conclusions: Two major factors were identified: (1) the lack of specialized library instruction addressed to doctoral students (in the case of Poland) and (2) the lack of promotion/ dissemination of such instruction among doctoral students and lecturers who could encourage their students to participate (in the case of France).

Research limitations: The response sample may be perceived too small to be representative for both universities; the method of identifying the field of studies may be disputable; the question if the universities in Lille and Warsaw are comparable might be posed.

Practical implications: This study might help librarians understand users' needs and define the gaps in the library offer. It also highlights the importance of the IL education in the university environment. Originality/value: This is the first study of its kind and the first comparative study conducted after the implementation of Bologna Process. It identifies the issues that might be considered and implemented by the libraries with the main one being the reinforcement of the role and importance of IL.
\end{abstract}

\section{Keywords}

Information literacy. Doctoral students. Comparative study. Grounded theory. France. Poland.

Received: 10.03.2014. Revised: 6.05.2014. Accepted: 10.05.2014.

\section{Introduction}

This paper summarizes the comparative research conducted in the frame of international doctoral thesis, prepared under joint supervision system (co-tutelle). The research aimed at shaping information literacy (IL) for enhancement of the use of scientific journals among doctoral students at the University of Lille (France) and the University of Warsaw (Poland). 


\section{Information literacy definition}

To describe the concept of information literacy (IL), it is good to take as a starting point the condensed definition that underlines the most crucial aspects of the problem. However, the widely described in literature issue is that one, universally accepted definition of the IL concept does not exist. As Carla Basili noted:

This is a complex phenomenon, which can be analyzed from several perspectives (Basili, 2008, 3),

thus several attempts to define IL can be found in the literature (see: ALA, 1989; Andretta \& Cutting, 2003; Basili, 2008; Feather, 2003; Johnston \& Webber, 2006; Lloyd, 2003; Wallis, 2005).

But still the most recognized and the most frequently cited definition of IL is that proposed by the American Library Association:

To be information literate, a person must be able to recognize when information is needed and have the ability to locate, evaluate and use effectively the needed information (ALA, 1989).

And the ALA's definition seems to be the most relevant also for the purpose of this paper.

\section{From library instruction to IL}

Traditionally, library instruction, known also as bibliographic instruction or library course took place in the library building and is aimed to familiarize the users with the library, its holdings, services, and rules of use. It was some kind of introduction to the library environment, including its resources, services and the psychical collections. In fact, it concentrated on using information tools rather than information searching and retrieval. It did not teach critical thinking and evaluative skills. The wide access to the complex information environment changed the role of librarians, from "gatekeepers" to "guides" (Wallis, 2005).

Andretta (2005) underlines the fact that the introduction of IL concept brought a change in library trainings. From tutor-centred (instructions imparted by a tutor at individual or group levels), they shifted to student-centred (with an independent learning approach). Also the mode of delivery changed: from library tours and orientation lectures to fully integrated and accredited units that cover information-seeking practices.

For Basili, library instruction is limited to holdings and services provided by the library and it is addressed only to library users, while IL

relates to every form of explicit, codified and recorded information, and is addressed to everyone who needs information for study or practical purposes (Basili, 2008,5).

According to Iannuzzi, IL is much more than library instruction as it incorporates conceptual, technical and critical thinking skills. So it

requires an institutional involvement that extends far beyond the library (Iannuzzi, 1999, 304).

The mentioned need of broader involvement will be the crucial factor discussed later in this paper. But, as Owusu-Ansah concluded: 
the crux remains user instruction, but no longer library user instruction. It is now information user instruction, with all the implications and expectations that the IL movement has come to propagate and stand for (Owusu-Ansah, 2004, 10).

That is why, in this paper, the terms "IL eduaction" and "library instruction" will be used synonymously.

\section{Translation problems and linguistic divagations}

The translation of the English term "information literacy" into other languages is always a major input in the development of IL in non-English speaking countries. However, the translation implicates not only the term, but also further consequences of understanding this term and its application. This is not only a linguistic but also a semantic matter.

In the case of French and Polish languages, the various translations (thus, understandings as well) can be noticed and this does not facilitate the unification of IL and creation of national IL standards.

Table 1. Polish and French synonyms and terms related to IL

\begin{tabular}{|l|l|}
\hline \multicolumn{1}{|c|}{ POLISH EQUIVALENTS } & \multicolumn{1}{c|}{ FRENCH EQUIVALENTS } \\
\hline umiejętność korzystania z informacji; & formation à la recherché documentaire; \\
umiejętność posługiwania się informacją; & formation à la recherché d'information; \\
umiejętność wyszukiwania informacji & formation à la méthodologie documentaire; \\
w różnych źródłach i mediach, jej selekcji, & formation des usagers; \\
krytycznej oceny oraz przetwarzania jej na & formation à la maîtrise de l'information; \\
własny użytek; & formation à l'usage de l'information; \\
biegłość w użytkowaniu informacji; & éducation à l'information; \\
umiejętności informacyjne; & formation à l'information; \\
kompetencje informacyjne; & alphabétisme informationnel; \\
edukacja informacyjna; & appropriation de l'information; \\
edukacja medialna; & compétence informationnelle; \\
sprawność informacyjna; & culture de l'information; \\
sprawne korzystanie z informacji; & culture informationnelle; \\
świadomość informacyjn;; & intelligence informationnelle; \\
alfabetyzm informacyjny. & méthodologie documentaire; \\
& méthodologie de l'information; \\
& littératie informationnelle. \\
\hline
\end{tabular}

Sources: Candalot Dit Casaurang, 2005; Chevillotte, 2004; Chevillotte, 2005; Denecker \& Durand-Barthez, 2011; Derfert-Wolf, 2009; Le Deuff, 2007; Martin, 2005; Serieyx, 1993; Université Lille 3, 2009.

In literal translation, in non-English speaking countries, "literacy" is a term connoted culturally, in no way equivalent to "literacy" used in the Anglo-Saxon literature. That is why it is so difficult to transpose it into other cultural worlds (Chevillotte, 2007). All countries that applied the IL concept and created their own standards, had to face this task. Two kinds of translation approach can be noticed: the literal and the more descriptive. The literal ones (as cited in Kurkowska, 2008) are for example: (Rus.) информационная грамотноть, 
(Cz.) informační gramotnost, (Sl.) informačná gramotnost', (Fin.) informaatiolukutaito, (It.) alfabetizzazione informativa. The second kind is the descriptive translation where the "literacy" is not translated as "alphabetization", but as "competencies". This is probably due to the fact that in these languages the "alphabetization" has the literal meaning of reading and writing skills (like in Polish; that will be discussed below). The selected foreign terms including word "competencies" are: (Ger.) Informationskompetenz, (Du.) informationskometence, (Se.) informationskompetens, (No.) informasjonskompetanse.

In French and Polish literature there is an ongoing debate regarding IL terminology. In both countries there have been several terms in use, this will be discussed in the next two sections, and still one national terminology has not been legitimized. Although, there is the need for a common language for Europe and, more globally, world-wide cooperation to facilitate collaboration in international project on IL.

To illustrate the importance of the problem, the terms describing IL used in French and Polish are presented in the table 1.

\subsection{Polish language}

In Polish literature related to IL, the problems with terminology and definition are widely discussed. Up to 2010 there was no official translation of the term "information literacy". Probably because there has not been any official institution or association that would take responsibility for the legal introduction of IL concept and standards to the Polish education system. In Polish literature various terms can be found, describing IL. The literal translation is "alfabetyzacja informacyjna", the term used most often in the literature, but not too handy in practical use as "alfabetyzacja" is connected with the teaching illiterate people reading and writing skills and in the common use it can have the pejorative association - if someone wants to give me the course of literacy, does it mean that I am illiterate?

The turning point was the establishment of an IL Committee (Pl. Komisja do spraw Edukacji Informacyjnej) within the Polish Librarians' Association (PLA) in 2010 (to be described in details in section 5.2). The Committee started to widely promote the Polish term "edukacja informacyjna" and in fact legitimized it. This appeared to be the best way and solved many issues related to that problem.

\subsection{French language}

In French, similarly as in Polish, the word "literacy" means reading skills and does not have the same meaning as in English. The French translation of the term 'IL' has never been easy and there is still a discussion among LIS professionals and scientists (Serres, 2008). The term chosen by IFLA and UNESCO to translate IL into French is "maîtrise de l'information". However, two other terms are also frequently used. These are "formation des usagers" (En. users' trainings) and "competences informationnelles" (En. information competencies). In the works written by non-librarians, the terms "culture de l'information" and "culture informationnelle" can be also found, used as synonyms of IL together with several others, presented in the table above. Serres (2008) conducted his own bibliometrical research to investigate which of these terms is the most common in French scientific literature and he found out that the most popular term is "maitrise de l'information" - the one proposed and promoted by 
the librarians. The number of publications using the term "culture de l'information" was two times less. The term "culture informationelle" was used even more infrequently.

\section{National undertakings in the domain of IL - a short review}

\subsection{IL in France}

In 1982 seven URFIST Centres (Regional Centres for Education in Scientific and Technical Information) were created by the Ministry of National Eduaction, Research and Technology. Their aim was to promote information training, providing professional education, particularly in new information technologies. Still, URFIST units are very active in the training of professionals (known in the literature also as training for trainers, formation de formateurs) (Candalot Dit Casaurand, 2004; Chevillotte \& Colnit, 2007; Juanals, 2003).

In 1997 the "The Deug Reform" was introduced in France (DEUG - Le diplôme d'études universitaires générales). This new law marked an important step in the history of information literacy education in France (Blin, 2008). It accelerated the process of integrating the information training (Fr. formation à l'information) into curricula.

In 1999 the "Bologna Agreement" - the reform of the studies at the European level was introduced in France. It helped to embed IL courses into the curricula. This caused them to be integrated as part of academic education (Chevillotte \& Colnot, 2007).

Also in 1999 a service FORMIST (FORMation à l'Information Scientifique et Technique - Training in the Use of Scientific and Technical Information) was launched by the French National School for LIS (ENSSIB). This is freely accessible online platform with the pedagogical and scientific resources on IL. It works on three axis: production and dissemination of educational materials, training of trainers, and information watch. As Chevillotte and Colnot (2007) write, many of the pedagogical resources are published thanks to the financial and institutional support from the state. FORMIST was also contributing the InfoLit Global Directory1 database, so the resources in French were internationally available and the guidance to information literacy can be useful in other countries. Moreover, since 2000, FORMIST has been organizing the annual conferences, called Rencontres FORMIST (en. FORMIST Meetings) to exchange ideas among French and foreign professionals.

In 1999-2000 the methodology modules (Fr. unites d'enseignement) were introduced into the academic curricula and in most cases became compulsory. This caused the reinforcement of library training and engaged the academic staff to cooperate with libraries. The complex training was organized and held together by the library and teaching staff. This also brought the opportunity to increase the length of courses (Blin, 2008; Ministère de l'Education Nationale, de la Recherche et de la Technologie, 1999).

In 2005 the survey on IL training at universities was conducted (Noel \& Cazaux, 2005). It showed that after introducing the Bologna Agreement, more and more courses were embedded into the curricula.

More information on IL undertakings in France can be found in literature (see: Blin, 2008; Chevillotte \& Colnot, 2007; Serieyx, 1993).

\footnotetext{
${ }^{1}$ Infolit Global Directory ceased to exist in mid-2013.
} 
In general, in France many activities in the domain of IL have been undertaken so far. However, as Chevillotte (2005) writes, there is still the need to be aware of what is going on in foreign countries. She underlines the role of FORMIST which organizes the workshops and conferences to present the works realized not only in France or French speaking countries but also worldwide. And there is still no law in France that would make the IL visible at an institutional or state level (Chevillotte \& Colnot, 2007).

\subsection{IL in Poland}

In Poland, LIS environment started to take interest in IL at the beginning of the 21st century. First, the focus was to explain the term, discuss the foreign literature and initiatives (mostly the Anglo-Saxon ones). There were also attempts to find the Polish equivalent for the English term.

Up to now, several research studies on IL were conducted (see: Batorowska, 2009; Jasiewicz, 2012; Kurkowska, 2012; Piotrowska, 2011).

However, since 2010 the IL PLA Committee has started the coordination of works aimed at wide implementation of IL into Polish ground and undertook the initiatives of promoting and popularizing IL in all types of libraries. The Committee translates international documents, organizes conferences and workshops, and publishes guides. It also cooperates with Polish and foreign institutions from the education and information sectors. It facilitates discussion on IL between Polish LIS practitioners and researchers and aspires to integrate IL into curricula at all stages of education.

In 2011 Polish State-of-the-art Report for IFLA purpose was elaborated and more information can be found there (Wiorogórska, 2011).

\section{The comparative study}

After defining the similarities and differences in French and Polish approaches to the IL problem, a comparative study among doctoral students of the University of Warsaw and the University of Lille was designed and conducted. The doctoral students were chosen as a target population because advanced and extensive research is a necessary task for them and IL skills seem to be indispensable. All 3789 doctoral students enrolled that time in studies at different faculties at the University of Warsaw (in total $1771 \mathrm{PhD}$ students) and the University of Lille (in total 2018 PhD students) were asked to take part in the survey. The comparative study was conducted on the sample consisted of 578 students (317 French and 261 Polish), representing all fields of study.

\section{Research design}

\subsection{Survey}

The survey was selected as the most appropriate approach to achieve a large sample. The survey method relies on a questionnaire instrument and is the most common method used in social science research. The survey questionnaire consisted of 27 closed and 
opened questions, both quantitative and qualitative. The questionnaire was prepared on the platform eSurveysPro.com and a link to it was distributed among the students.

The first part of the survey consisted of 21 detailed questions. They concerned use of information holdings of University of Warsaw and University of Lille libraries, and inquired whether doctoral students are familiar with the libraries electronic and traditional catalogues, and printed and electronic journals. The questions concerned the IL education as well as the potential obstacles while using scientific journals that the libraries provide.

The second part of the survey, six demographic questions, was designed to gather the basic respondents characteristics, including: gender, year of studies, field of science, English and other languages proficiency.

In spite of dividing the questionnaire into two parts and arranging the questions in a consequent sequence, the survey aimed not to be too tight. The Babbie's suggestion, underlining the need of free ordering items in questionnaire that significantly facilitates the data analysis work afterwards was followed (Babbie, 2008, 281-282).

\subsection{Observations}

Following Hargittai \& Hinnant it should be stressed that

for an in-depth understanding of people's information-seeking behaviour, in-person observations (...) can be especially insightful. Such studies are not uncommon in the LIS literature (Hargittai \& Hinnant, 2006, 63).

In the case of this research covert participant observations were applied. It means that the observer did not declare his or her presence and intentions, in order to not distort the behavior of the observed population. This was also done because certain situations can be observed in secret only to make a research credible (De Ketele \& Roegiers, 2009).

\subsection{Grounded theory}

The term grounded theory (GT) was used for the first time by Barney Glaser and Anselm L. Strauss in their book The discovery of grounded theory. Strategies for qualitative research (1967). GT is a quantitative research method that aims at developing theory from data systematically obtained from an empirical social research and not at the stage of literature review and definition of hypothesis.

GT is one of interpretive methodology - research is conducted from an experience-near perspective and the researcher does not start with hypothesis determined a priori, but rather wants to emerge data from the field. Besides, GT is quite flexible: there are no strict research principles. Perhaps that is why GT is not frequently applied as it might seem unclear and unspecified.

GT has many different interpretations and variants of implementation. As Ian Dey writes:

(...) there are probably as many versions of grounded theory as there were grounded theorists (Dey, 1999, 2). 
GT allows flexibility in approach and in application. It does not require following all process, and it allows different interpretations. The authors of the concept leave the door open, saying that

grounded theory (...) may take different forms (Glaser \& Strauss, 1967, 31).

All stages of work with GT are extensively described in the literature (see: Glaser \& Strauss, 1967; Mansourian, 2006; Tan, 2010; Wiorogórska, 2012). The way GT has been realized in this study is described below.

\section{Research process}

(1) No literature review was made before the survey. This is one of GT principles:

a. An effective strategy is, at first, literally to ignore the literature of theory and fact on the area under study, in order to assure that the emergence of categories will not be contaminated by concepts more suited to different areas (Glaser \& Strauss, 1967, 37).

(2) The starting point of this study was the hypothesis suggesting that the use of scientific journals is low compared to their high educative and scientific value. It seemed relevant to investigate whether it is connected with IL education at both universities.

(3) Data collection. The tool used at this stage (the questionnaire) was described earlier, in section 7.1. However, data collection was based not only on the questionnaire but also on observations made during the work field, meaning in the libraries of two universities being the subject of investigation. A comparative analysis of data collected in these two ways, based on the principles of GT, was realised in four stages described below.

a. Data coding and comparing the applicable occurrences of each category. The qualitative data were coded under conceptual categories elaborated before. Those were: "library instruction and its effect", "use of scientific journals and its problems", "use of catalogues and its problems". Each category was allotted its properties (that describe systematic relations). For example, the category "use of scientific journals and its problems" was described by the following properties: "complex access", "mastery", "lack of assurance", "lack of instruction", "language problems", "use imposed by lecturer". The analysis and simultaneous comparison of two groups of students (French and Polish) allowed to describe the relations and to classify data into appropriate categories. This also allowed indicating certain subjects to develop during the field observations (for example the problem related to IL education offer) and to suggest hypotheses related to specific situations - for this stage memo writing is useful.

b. Integration of categories and their properties. This stage served to link the groups of categories, their relations and determination of the concept. All categories having "lack of assurance" as a property were analysed and regrouped to the category "incertitude". The categories "use of scientific journals" and "use of catalogues" were connected and created one category "library resources and 
tools and their use". These actions allowed limiting the number of categories and to start the next stage of work.

c. Delimitating the theory. At this stage hypothesis are clarified and their number are limited, leaving only the most regular categories. This is also the stage when category saturation is attained. To be sure that categories established earlier are saturated, the additional observations were made to verify if the lack of certitude and the difficulties with the use of scientific journals and tools offered by the libraries are linked with the insufficient library instruction or even with its absence.

d. Generation of theory. As Glaser and Strauss writes,

(...) to generate substantive theory, we need many facts for the necessary comparative analysis (Glaser \& Strauss, 1967, 35).

At this stage all coded data must be managed. This is the appropriate moment for gathering memos and developing a theory. The theory generated in this study helped indentify the factors that influence the lower use of resources and tools offered to students by the libraries in two countries. Two major factors were identified: (1) the lack of specialised library instruction, dedicated to doctoral students (in the case of Poland) and (2) the lack of promotion or popularisation of such instruction among doctoral students and lecturers who could encourage their students to participate (in the case of France). The information users who are not aware of the existence of certain resources or tools or who cannot explore all their functionalities (like: advanced options, data screening, data sorting, etc.) either abandon the use of these resources or use them superficially and do not benefit from their whole richness.

As Pickard (2007) underlines, the goal of the research clarifies during observations and data collecting. This proves that the researcher must be prepared for discovery of non-previewed earlier and unexpected events. That lack of stable initial hypothesis means that there is no necessity of its later verification - as all hypotheses are the status "suggested" and they are clarified and verified during the research progress. A new hypothesis can appear at every stage of research as well.

This study, at the beginning aiming principally at investigation of the issue of use of scientific journals, broadened afterwards. The implications and contributions of the study elaborated on the basis of generated theory are described below.

\section{Implications of the study}

On the basis of this study results the following implications are suggested for librarians, university libraries administrators, faculty, and university administration.

(1) This study might be helpful for librarians to understand users' needs and to define the gaps in the libraries offering. It also highlighted the importance of the IL education at the university forum.

(2) The findings of the study present a set of implications that might be considered by the policy makers as well as by the library and university administrators.

(3) There is a need for professionalization of the pedagogical role of librarians. Training the trainers should be organized for librarians, to allow them to acquire the 
necessary pedagogical skills and tools. The self-assured librarians will be able to prepare more attractive IL education offer and promote it at the university forum. Librarians need to become perceived as educators within their university (Torras \& Saetre, 2009; Williamson et al., 2007).

(4) The IL education offer should be developed and adjusted to the particular needs of doctoral students. The training for each discipline should be elaborated.

(5) There is a need for enhanced promotion of library services and library's educational offer. However, it cannot be done without realisation of the activities described in point 1 and 2 .

(6) The results of this study can also pose a critical reflection on libraries acquisition policy related both to scientific journals (printed and electronic) and tools, like: multisearching systems, bibliography management systems, or e-learning platforms.

\section{Major contributions of the study}

This study results in a number of contributions.

(1) This is the first study of its kind. The examination of LIS literature revealed that no comparative study between France and Poland had been realized earlier, not only in the domain of IL and doctoral students, but generally in LIS.

(2) This is also the first comparative study realised during the implementation of Bologna Process. A reminder for the reader: Bologna Process aims, generally, at unifying the European Union higher education, transfer of knowledge, and adoption of qualification frameworks of the European Higher education Area (Council of Europe, 2010).

(3) As Wilson (2000) writes,

information research (...) must be related to the organisations or organisational sub-units in which information work is practiced.

The wish for this study is that its findings and conclusions would find application. Naturally, it might be realised easier in the case of Poland as the field of investigation (i.e. University of Warsaw) is a workplace of the study's author.

(4) This study also identifies the issues that might be considered and implemented by libraries. The main one is the reinforcement of the role and importance of IL. The existing offer of IL instructions should be improved and adjusted to doctoral students' needs. Besides, in the long term, library authorities should advocate for implementing IL into universities strategic plans and, what comes along, for integrating IL into curriculum, according to the guidance of Bologna Process Qualifications Framework for European Higher Education Area, the so-called Dublin Descriptors (Bologna Working Group on Qualifications Framework, 2005; Council of Europe, 2010). 


\section{Limitations of the study}

Although this study was conducted with a sincere regard to methodology that was precisely considered and chosen with reference to the literature of the IL subject as well as to the other LIS works, there are certain limitations that might be perceived as weaknesses and have influenced results, findings, and contributions of this study. These are as follows:

(1) The response sample can be perceived as too small to be representative for both universities. To recall: $14.73 \%$ for the University of Warsaw and $15.70 \%$ for the University of Lille. However, it is hard to force respondents to take part in the study and to influence their unwillingness to take part in the survey, although the participation was recommended by doctoral studies authorities and administration. In the case of this study, the goal was to investigate the largest possible number of respondents. Regarding the number of respondents from the percentage angle might provoke doubts, but regarding the real numbers of respondents ( 261 for the University of Warsaw and 317 for the Universities of Lille) provides 578 students who showed their willingness to contribute to this study and decided to dedicate their time.

(2) The field of studies partition can be disputable. In this study respondents were asked to indicate their domain among: applied sciences, humanities, pure sciences, and social sciences. This might provoke questions, especially in the light of other studies. Generally, disciplinary differences are complex and important. Especially that there are differences in the structure of knowledge and research techniques between sciences. They affect teaching methods and student learning (Entwistle as cited in Sanderson, 2011). As Hjørland (cited in Talja \& Maula, 2003) deduces, domains differ in their theoretical views, paradigms, and epistemological assumptions, thus also in their general relevance criteria. For Collins and Jubb (2012) even within one discipline the sub-groups can be identified. Moreover, even at local level, the habits of colleagues or collaboration can have an effect upon information behavior. Talja and Maula (2003) are of the opinion that analysis of the field must be narrower than for example "humanities" or "applied sciences" research.

(3) The question whether universities in Lille and Warsaw are comparable might be posed. There are indeed many differences (geographical, economical, developmental, or educational) but both universities are located in the European Union, both are implementing the Bologna Process and are members of the European Research Area. Thus, at least for this reason both can definitely be the subject of comparative study.

\section{Further studies directions}

This research study suggested a number of recommendations and identified key-implications and conclusions. Besides, it enabled the indication of the areas for future research that might be developed, keeping in view the following issues:

(1) Grounded theory research. A potential study on IL can be conducted, applying the whole process of work with GT. However, as GT is a very demanding methodology, 
it would be recommended to realise such a study by a group of researchers and not by an individual one.

(2) An in-depth and cross-disciplinary study research might be conducted to investigate complex relationships between field of study and information needs, taking into consideration all differences between fields of study as described earlier.

(3) There is a need for working on the universities forums, aiming at the legitimisation of IL and its implementation into university strategies and curricula in both countries.

(4) To this end, the cooperation between librarians and faculty and a common advocacy for IL at the university administration level is absolutely required.

(5) To enhance the research on IL and information users in both countries, a "library research groups" might be established to guarantee studies systematically conducted with regard to the currently applied social sciences methodology.

(6) This study revealed that libraries must develop their IL education programmes and be more focused on particular fields of study instead of preparing one, uniform offer. This finding goes along with the opinion of Marie-Laure Malingre and Alexandre Serres (2011) who underline that the uniform IL education for doctoral students does not exist analogically to information practice that differs from one discipline to another.

\section{References}

ALA (1989). American Library Association Presidential Committee on Information Literacy: final report [online]. American Library Association, [08.03.2014], http://www.ala.org/ala/mgrps/divs/ acrl/publications/whitepapers/presidential.cfm

Andretta, S. (2005). Information literacy: a practitioner's guide. Oxford: Chandos Pub.

Andretta, S.; Cutting, A. (2003). Information Literacy: A Plug-and-Play Approach. Libri, 53(3), 202-209.

Babbie, E. (2008). The basics of social research (4th ed.). Belmont CA: Thomson/Wadsworth.

Basili, C. (2008). Theorems of Information Literacy. A mathematical-like approach to the discourse of Information Literacy [online]. In: M. Kocójowa (red.) Biblioteka - klucz do sukcesu użytkowników (ePublikacje Instytutu Informacji Naukowej i Bibliotekoznawstwa, nr 5). Instytut Informacji Naukowej i Bibliotekoznawstwa, Uniwersytet Jagielloński, [08.03.2014], http://eprints.rclis.org/14010/.

Batorowska, H. (2009). Kultura informacyjna w perspektywie zmian w edukacji. Warszawa: Stowarzyszenie Bibliotekarzy Polskich.

Blin, F. (2008). 25 years of a continous national policy: information literacy networking in higher education in France. In: J. Lau (ed.) Information literacy: international perspectives. Munchen: K.G. Saur, 27-49.

Bologna Working Group on Qualifications Framework. (2005). A Framework for Qualifications of the European Higher Education Area [online]. [08.03.2014], http://www.bologna-bergen2005.no/ Docs/00-Main_doc/050218_QF_EHEA.pdf

Chevillotte, S. (2004). La formation à la maitrise de l'information à l'heure européenne: problèmes et perspectives. Villeurbanne: Presses de l'ENSSIB École nationale supérieure des sciences de l'information et des bibliothèques.

Chevillotte, S. (2005). Bibliothèques et Information Literacy. Un état de l'art. Bulletin des Bibliothèques en France, 50(2), 42-49.

Chevillotte, S. (2007). Maitrise de l'information? Education a l'information? Culture informationnelle? Les Dossiers de L'Ingenierie Educative, 57, 16-19. 
Chevillotte, S.; Colnot, A. (2007). French Speaking Countries: Belgium, France, Quebec, Switzerland Information Literacy State-of-the-Art Report [online]. International Federation of Library Associations and Institutions, [08.03.2014], http://www.ifla.org/files/assets/information-literacy/ publications/il-report/france-2007.pdf

Collins, E.; Jubb, M. (2012). How do Researchers in the Humanities Use Information Resources? LIBER Quarterly, 21(2), 176-187.

Council of Europe. (2010). Bologna for pedestrians [online]. Council of Europe, [08.03.2014], http://www.coe.int/t/dg4/highereducation/ehea2010/bolognapedestrians_EN.asp?

De Ketele, J.-M.; Roegiers, X. (2009). Méthodologie du recueil d’informations fondements des méthodes d'observation, de questionnaire, d'interview et d'étude de documents. Bruxelles: De Boeck.

Denecker, C.; Durand-Barthez, M. (2011). La formation des doctorants à l'information scientifique et technique. Villeurbanne: Presses de l'ENSSIB.

Derfert-Wolf, L. (2009). Information literacy - kształcenie umiejętności informacyjnych w bibliotekach akademickich. W: B. Antczak-Sabała; M. Kowalska; L. Tkaczyk (red.) Przestrzeń informacyjna biblioteki akademickiej - tradycja i nowoczesność: praca zbiorowa. Toruń: Wyższa Szkoła Bankowa, 185-208.

Dey, I. (1999). Grounding grounded theory guidelines for qualitative inquiry. San Diego: Academic Press.

East, J. W. (2005). Information Literacy for the Humanities Researcher: A Syllabus Based on Information Habits Research. The Journal of Academic Librarianship, 31(2), 134-142.

Feather, J. (2003). International encyclopedia of information and library science (2nd ed.). London; New York: Routledge.

Glaser, B.; Strauss, A. L. (1967). The discovery of grounded theory strategies for qualitative research. Chicago: Aldine Pub. Co.

Hargittai, E.; Hinnant, A. (2006). Toward a Social Framework for Information Seeking. In: A. Spink \& C. Cole (eds.), New Directions in Human Information Behavior. Dordrecht: Springer, 55-70.

Iannuzzi, P. (1999). We are teaching, but they are learning: accountability, productivity , and assessment. The Journal of Academic Librarianship, 25(4), 304-305.

Jasiewicz, J. (2012). Kompetencje informacyjne mtodziezy analiza - stan faktyczny - ksztatcenie na przyktadzie Polski, Niemiec $i$ Wielkiej Brytanii. Warszawa: Wydaw. SBP.

Johnston, B.; Webber, S. (2006). As we may think: Information literacy as a discipline for the information age. Research Strategies, 20(3), 108-121.

Juanals, B. (2003). La culture de l'information: du livre au numérique. Paris: Hermès science publications.

Kurkowska, E. (2012). Edukacja informacyjna w bibliotekach a rozwój spoteczeństwa wiedzy. Warszawa: Wydaw. SBP.

Kurkowska, E. (2008). Information literacy - problemy terminologiczne. Toruńskie Studia Bibliologiczne, 1, 71-81.

Le Deuff, O. (2007). La culture de l'information: quelles "litteraties" pour quelles conceptions de l'information? Organisation des connaissances et societé des savoirs: concepts, usages, acteurs. Actes du 6 e colloque international du chaptire français de l'ISKO. 7 et 8 juin 2007, Toulouse, 97-115.

Lloyd, A. (2003). Information Literacy: The Meta-Competency of the Knowledge Economy? An Exploratory Paper. Journal of Librarianship and Information Science, 35(2), 87-92.

Malingre, M.-L.; Serres, A. (2011). Une culture informationnelle commune aux doctorants? Le pari de Form@doc. In C. Denecker \& Durand-Barthez Manuel (eds.), La formation des doctorants à l'information scientifique et technique. Villeurbanne: Presses de l'Enssib, 53-67.

Mansourian, Y. (2006). Adoption of grounded theory in LIS research. New Library World, 107(9/10), 386-402.

Martin, T. (2005). La formation à la recherche d'information dans l'enseignement supérieur en filière scientifique: contextes institutionnel et scientifique, exemple d'une formation à la maîtrise de l'information. Documentaliste - Sciences de l'information, 42(3), 190-199. 
Ministère de l'Éducation Nationale de la Recherche et de la Technologie. (1999). Former les étudiants à la matrise de l'information: repères pour l'élaboration d'un programme. Paris.

Noel, E.; Cazaux, M.-A. (2005). Enquête sur la formation à la méthodologie documentaire. Bulletin des Bibliothèques en France, 50(6), 24-28.

Owusu-Ansah, E. K. (2004). Information Literacy and Higher Education: Placing the Academic Library in the Center of a Comprehensive Solution. Journal of Academic Librarianship, 30(1), 3-16.

Pickard, A. (2007). Research methods in information. London: Facet.

Piotrowska, R. (2011). Edukacja informacyjna w polskiej szkole. Warszawa: Wydaw. SBP.

Sanderson, H. (2011). Using Learning Styles in Information Literacy: Critical Considerations for Librarians. The Journal of Academic Librarianship, 37(5), 376-385.

Serieyx, H. (1993). Former et apprendre à s'informer: pour une culture de l'information: formation a l'usage de l'information. Paris: ADBS Editions.

Serres, A. (2008). La culture informationnelle. In: F. Papy (ed.) Problématiques émergentes dans les sciences de l'information. Paris: Lavoisier, 137-159.

Talja, S.; Maula, H. (2003). Reasons for the use and non-use of electronic journals and databases. Journal of Documentation, 59(6), 673-691.

Tan, J. (2010). Grounded theory in practice: issues and discussion for new qualitative researchers. Journal of Documentation, 66(1), 93-112.

Torras, M. C.; Saetre, T. P. (2009). Information literacy education: a process approach: professionalising the pedagogical role of academic libraries. Oxford: Chandos Pub.

Tujague Candalot Dit Casaurang, C. (2004). Formation aux competences informationnelles en premier cycle universitaire: études et reflexions. Unpublished doctoral dissertation.

Tujague Candalot Dit Casaurang, C. (2005). L'identité professionnelle des formateurs à la recherche documentaire en premier cycle universitaire. Documentaliste - Sciences de l'information, 42(3), 200-209.

Universite Lille 3 Questionnaire de rentree pour les doctorants (2009). Document for internal use only. Wallis, J. (2005). Cyberspace, information literacy and the information society. Library Review, 54(4), $218-222$.

Williamson, K.; Bernath, V.; Wright, S.; Sullivan, J. (2007). Research students in the electronic age. Communications in Information Literacy, 1(2), 47-63.

Wilson, T. D. (2000). Recent trends in user studies: action research and qualitative methods. Information Research [online], 5(3), [08.03.2014], http://informationr.net/ir/5-3/paper76.html

Wiorogórska, Z. (2011). Poland. Information literacy state-of-the-art report [online]. International Federation of Library Association and Institutions, [08.03.2014], http://www.ifla.org/files/assets/ information-literacy/publications/il-report/poland-2011.pdf

Wiorogórska, Z. (2012). Teoria ugruntowana i jej wybrane zastosowania w badaniach z zakresu informacji naukowej i bibliotekoznawstwa. Przeglad Biblioteczny, 80(1), 47-57.

\title{
Edukacja informacyjna a doktoranci we Francji i w Polsce. Badanie porównawcze
}

\begin{abstract}
Abstrakt
Cel/teza: rtykuł ma na celu przybliżenie zagadnienia edukacji informacyjnej (ang. information literacy) w perspektywie francusko-polskich badań porównawczych użytkowników informacji. W pierwszej części omówione są podobieństwa i różnice w polskim i francuskim podejściu do
\end{abstract}


problematyki edukacji informacyjnej w szkolnictwie wyższym, następnie przedstawiono wyniki badań przeprowadzonych wśród doktorantów Uniwersytetu Warszawskiego i Uniwersytetu w Lille. Koncepcja/metody badań: W badaniu wykorzystano trzy metody badawcze: ankietę, ukrytą obserwację oraz elementy teorii ugruntowanej. Badanie miało na celu zweryfikowanie hipotezy o zbyt niskim wykorzystaniu czasopism naukowych przez doktorantów oraz odpowiedzenie na pytanie, jakie działania powinni podjąć bibliotekarze i wykładowcy, aby je zwiększyć.

Wyniki i wnioski: Zidentyfikowano dwa główne czynniki: (1) brak wyspecjalizowanej edukacji informacyjnej, skierowanej do doktorantów (w przypadku Uniwersytetu Warszawskiego), (2) brak promocji czy popularyzacji edukacji informacyjnej wśród doktorantów i wykładowców, którzy mogliby zachęcić studentów do uczestniczenia w szkoleniach (w przypadku Uniwersytetu Lille).

Ograniczenia badań: Próba badawcza może być postrzegana jako niereprezentatywna dla obu uniwersytetów; sposób wydzielenia dziedzin nauki może być dyskusyjny; można zastanawiać się, czy Uniwersytet Warszawski i Uniwersytet w Lille mogą być przedmiotem badań porównawczych. Zastosowanie praktyczne: Niniejsze badanie może być pomocne dla bibliotekarzy w zrozumieniu potrzeb użytkowników i zdefiniowaniu braków w ofercie bibliotecznej. Badanie podkreśla także wagę edukacji informacyjnej na forum uczelni.

Oryginalność/wartość poznawcza: Dotychczas nie przeprowadzono żadnych francusko-polskich badań porównawczych w dziedzinie edukacji informacyjnej; jest to także pierwsze badanie porównawcze zrealizowane po wdrożeniu Procesu Bolońskiego; niniejsze badanie zidentyfikowało rozwiązania, które biblioteki mogą rozważyć i ewentualnie wdrożyć. Głównym wskazaniem jest wzmocnienie roli i wagi edukacji informacyjnej.

\section{Słowa kluczowe}

Badania porównawcze. Doktoranci. Edukacja informacyjna. Francja. Information literacy. Polska.

Teoria ugruntowana.

Dr ZUZANNA WIOROGÓRSKA is an academic librarian working at the University of Warsaw Library. She is a member of IFLA Information Literacy Section and the co-founder of Information Literacy Commission within Polish Librarians' Association. She was a scholar of French Government (2010-2013). Her research interests include scientific journals, information literacy, information users, 21st century skills. The most important recent publications: Wiorogórska, Z. (2012). Teoria ugruntowana i jej wybrane zastosowania w badaniach z zakresu informacji naukowej i bibliotekoznawstwa. Przeglad Biblioteczny, 80(1), 47-57; Wiorogórska, Z., Rehman, S. U. (2012). When librarians became researchers. The creation of international culture of knowledge sharing beyond the borders. Pakistan Library and Information Science Journal, 43(2), 22-33; Wiorogórska, Z. (2013). Edukacja informacyjna statym elementem programu studiów? W: M. Wrocławska \& J. Jerzyk Wojnecka (red.), Biblioteka w komórce? Przysztość ustug bibliotecznych. Międzynarodowa Konferencja Biblioteki Uniwersytetu Łódzkiego, 4-6.06.2013. Łódź, Wydawnictwo Uniwersytetu Eódzkiego, 179-188.

Contact to the Author: $z$.d.wiorogorska@uw.edu.pl

Biblioteka Uniwersytecka $w$ Warszawie

ul. Dobra 56/66

00-312 Warszawa 